\title{
Perceived Risk and Knowledge of COVID-2019 Community Transmission among Local Council Leaders in Rural Districts of Eastern Uganda
}

Abdul Walusansa ( $\sim$ abdulwalusansa@gmail.com )

Islamic University in Uganda https://orcid.org/0000-0001-9769-1343

Jacob Stanley Iramiot

Busitema University

Ali Kudamba

Islamic University in Uganda

Shaban Alemu Okurut

Islamic University in Uganda

Joseph Mpagi

Busitema University

Aidah Namuli

Islamic University in Uganda

Hawa Nabuuma

Islamic University in Uganda

Wasige Godfrey

Islamic University in Uganda

Hussein M. Kafeero

Islamic University in Uganda

Jamil Ssenku

Islamic University in Uganda

\section{Research}

Keywords: COVID-19, SARS-Cov.2, Uganda, rural communities, Corona virus

Posted Date: December 10th, 2020

DOl: https://doi.org/10.21203/rs.3.rs-123401/v1

License: (c) (1) This work is licensed under a Creative Commons Attribution 4.0 International License.

Read Full License 


\section{Abstract}

Background: Corona virus disease (COVID-19) is one of the topmost global hindrances to human existence. Rural settings have been reported to be more vulnerable in some parts of the world. In Uganda, local council (LC) leaders in rural districts are among the immediate personnel mandated to support compliance with preventive guidelines, and to identify and report/deliver COVID-19 cases to health units. We examined the potential risk of COVID-19 transmission, knowledge levels, perceptions \& opinions of LC leaders in selected districts in Eastern Uganda, to support the design of risk-based COVID-19 control measures in rural settings, to protect lives better.

Methods: A convenience sample was taken from village council leaders in the selected districts. Pretested questionnaires and in-depth interviews were used to assess the knowledge levels, perceptions, and opinions of respondents about COVID-19. An observational survey was also conducted to examine the barriers that might deter effective control of COVID-19, with reference to health guidelines set by the Ugandan government and the World Health Organization. Data was analyzed using HyperRESEARCH 2.8 software, and STATA version-15.0.

Results and discussion: Eighty percent of local council leaders reported that they were formally engaged in the fight against COVID-19 in their communities, and the common means of engagement were; dissemination of COVID-19 information by word of mouth, regulation of public events, and monitoring of visitors that come from distant places. All clients reported having received some information about this pandemic, but there was generally low knowledge on some vital aspects: $70 \%$ of the respondents did not know the meaning of COVID-19; $100 \%$ were uninformed on these common symptoms; headache, sore throat, nausea, and loss of taste \& smell; $10 \%$ did not know if willingness to conform to health guidelines may affect COVID-19 prevention, and they believed that domestic animals are viable vectors. Radio was the commonest source of COVID-19 information, but it was confounded by poor quality of radio-signals. Most respondents were of the view that in the communities they lead; inaccessibility to authentic health information, financial constraints, and belief that COVID-19 is a fallacy, were some of the leading obstacles to the fight against the pandemic. Low awareness and misconceptions on COVID-19 could be explained by; technological challenges, low literacy levels, and dissemination of wrong information about this pandemic. From the observational survey, the major factors which might intensify the risk of COVID19 spread were: scarcity of requirements for hand hygiene, face protection, violation of health guidelines $\&$ directives, porous borders, terrain, and use of potentially polluted open water sources.

Conclusion and recommendations: Rural communities in Eastern Uganda are vulnerable to the drastic spread of COVID-19, due to challenges related to: low awareness of COVID-19, reluctance in complying with preventive guidelines, finance, technology, terrain, porous borders, illiteracy and scarcity of protective wear and hygiene resources. Awareness creation, material aid, execution of preventive rules, and more research on COVID-19 are warranted.

\section{Introduction}


The recent global outbreak of severe acute respiratory syndrome corona virus-2 (SARS-CoV.2), has become the greatest public health challenge faced by mankind in the 21 st century $(1,2)$. The Corona virus disease 2019 (COVID-19), caused by SARS-Cov.2, has so far infected over 44,002,003 people, claimed over 1,167,988 lives, and triggered severe economic and societal disruptions world over (3). In some parts of the world, rural communities have been reported to be potentially more susceptible to the devastation of COVID-19 than urban populations (4). The pandemic has mounted graver societal impacts on resource-poor countries, mostly in Africa, where the majority of the populations are small scale daily income earners (5). In Uganda where COVID-19 has so far caused over 11621 infections and 103 deaths, the country was recently commended by World Health Organization (WHO) as a model state in averting the community spread of this pandemic $(5,6)$. However, the infection rates in Uganda are now intensifying, and the country is feared to slide into the same scenario as other badly-hit countries $(6,7)$. Anti-COVID-19 advocacy in Uganda is somewhat more intense in urban places. In the Eastern part of Uganda, several urban places have been reported to be COVID-19 hotspots (8-10). This creates a potential risk of COVID-19 spread to the nearby rural settings through an influx of urban-dwelling individuals such as: traders, researchers, among other categories. This pandemic might cause severe damage in rural settings than urban places of Uganda because the former are commonly associated with challenges such as illiteracy, inadequate access to health services, and high population, which may escalate COVID-19 spread $(11,12)$. The first line of defense against a highly contagious disease such as COVID-19 is the prevention of spread (13). To achieve this, communities need to be supported, especially in terms of public health awareness, material aid, and enforcement of preventive guidelines (14). In this regard, the ministry of health in Uganda established a gazette which constitutes public health protocols and guidelines to curb community spread of COVID-19 (14). The gazette mandates village council leaders to actively engage in COVID-19 control processes in the respective villages they lead. These local council leaders are now among the most immediate personnel available to monitor compliance the COVID-19 preventive guidelines in rural communities, and to identify and report/deliver potential COVID-19 cases to medical practitioners (14). Therefore, in the current research we examined the knowledge levels, perceptions and opinions about COVID-19 among village council leaders, and the factors that might accelerate community transmission of COVID-19 in selected rural districts of Eastern Uganda. The aim was to support the design and effective implementation of risk based COVID-19 control measures in rural settings, in order to avert death and protect livelihoods.

\section{Materials And Methods \\ 2.1 Study Site}

This study was conducted in three selected rural districts in Eastern Uganda, namely: Butalejja, Sironko, and Bulambuli. Participants were from six villages, which they administer as local council leaders, viz: Buluganya \& Namango villages in Bulambuli district; Zerembu village in Sironko district; Budoba, Mulanga \& Bubuhe villages in Butalejja district. The districts are close to the Uganda-Kenya border. During data collection, geo-referenced coordinates were recorded using the geographic position system 
(GPS) machine (GARMIN, GPSmap 60CSx). The coordinates were then used for mapping up the study area (Fig. 1).

\subsection{Demographic characteristics of the population.}

The study focused on selected local council leaders who are mandated to participate in COVID-19 control in Butalejja, Sironko, and Bulambuli districts in Eastern Uganda. The total population of the three districts that constituted our study area was 661,083; i.e. 174, 508 in Bulambuli district; 242, 422 in Sironko district and 244, 153 in Butalejja district (15). Most of the people are peasant farmers, with relatively high levels of monetary poverty and illiteracy (16).

\subsection{Study Design}

A qualitative cross-sectional study was conducted using questionnaires, in-depth interviews, and an observational survey.

\subsection{Sampling}

A convenience sampling technique was adopted where local council leaders were recruited from purposively selected villages in the districts of interest. The study was designed to cover village local council one chairpersons and/or local council two chairpersons, plus key local council women leaders who potentially perform any roles in executing COVID-19 control strategies in their villages of jurisdiction. Ten local council leaders were purposively selected from six villages. The participants were assigned study codes during data collection.

\subsection{Data collection}

Participants were subjected to pretested, researcher administered, structured questionnaires to examine their knowledge levels on the general aspects of COVID-19, it's routes of spread, and prevention approaches. In-depth interviews were conducted on the participants to seek information about their assigned and/or voluntary duties in COVID-19 control, as well as their perceptions and opinions about this pandemic. Also, observations were made by the researchers across the six villages to check for conformity to the COVID-19 preventive guidelines, the preparedness of the rural communities to counteract the spread of COVID-19, and topographical factors that might predispose the rural communities to a drastic upsurge of the COVID-19 pandemic. Our observations were guided by local and international recommendations that have been set for curbing COVID-19 spread in homesteads and public places $(14,17,18)$.

\subsection{Data management}

The filled questionnaires were checked for consistency and completeness before the final data processing and analysis. All data was double-entered into a Microsoft excel database which was password protected. All the data related to the participants were coded and the codes were only known to the research team to ensure confidentiality and integrity of the participants' responses. Hard copies of the 
data from the interviews and questionnaires were kept in locked file cabinets and all the data were reported as anonymous without referring to the specific indemnifiers of individual clients.

\subsection{Data analysis}

This was done concurrently with data collection with a continuous reflection about the data for themes or issues set out to be studied following a coding procedure. Descriptive statistics were used to report the frequency of categorical variables. The results were presented in frequency tables, pie charts, and bar graphs. Data was analyzed using HyperRESEARCH 2.8 software, and STATA version-15.0.

\section{Results}

\subsection{Socio-Demographic Characteristics}

Ten local leaders participated in the survey, and gave a reflection of the status of COVI-19 prevention in the six villages. Eight participants were males while two were females. Six of the respondents were local council one chairmen, two were local council two chairmen, while two respondents were women leaders on village council committees (Fig. 1). Most participants fell in the age category of $\geq 60$ years $(50 \%)$ while the minority were aged $30-40$ years (10\%) (Table 1$)$. 
Table 1

Socio-Demographic Characteristics of local leaders that execute assigned and/or voluntary COVID-19 control activities in selected rural villages in Eastern Uganda

\begin{tabular}{|llll|}
\hline Characteristic & & Frequency & Percentage (\%) \\
\hline Gender & Male & 8 & 80 \\
\hline Age (years) & Female & 2 & 20 \\
\hline \multirow{5}{*}{ Nationality } & $30-40$ & 1 & 10 \\
\hline & $41-50$ & 2 & 20 \\
\hline Marital status & $51-60$ & 2 & 20 \\
\hline \multirow{5}{*}{ Education } & Ugandan & 5 & 50 \\
\hline & Non-Ugandan & 10 & 100 \\
& Married & 0 & 0 \\
\hline & Single & 10 & 100 \\
\hline & None & 0 & 0 \\
\hline Leadership Position & Local council I (LC-I) chairmen & 6 & 10 \\
\hline & Secondary & 2 & 60 \\
\hline & Other & 2 & 20 \\
\hline & Women LC-I leaders & 3 & 20 \\
\hline
\end{tabular}

In terms of education, $60 \%$ of the participants attended the primary level of education while $10 \%$ did not attain any formal education completely as shown in Fig. 2.

\subsection{Knowledge, perceptions, and opinions of local leaders about COVID-19}

\subsection{General knowledge about the COVID-19 pandemic}

Respondents answered questions to enable the research team to assess the participants' knowledge about COVID-19. The questions ranged from the basic understanding of COVID-19; to the core aspects of 
the disease including: epidemiology, signs and symptoms, risk factors and prevention strategies. All the participants reported having received some information about the existence of the Corona virus-2019 phenomenon. Sources of COVID-19 related information varied significantly among the respondents; with radio being the most common source of COVID-19 information (90\%) and peers being the least (10\%) (Fig. 3).

Respondents who reported to have prior knowledge about COVI-19 were asked to outline the meaning of the COVID-19 pandemic. Participants with correct knowledge to the meaning of COVID-19 constituted $30 \%$ while those with incorrect information accounted for $70 \%$. Some of the correct answers given included, "new deadly flue and cough associated with pneumonia and suffocation to death", while some of the wrong answers included; "New deadly disease that kills in a very short time (30\%), "One coughs when he touches the face or nose (10\%)", "new serious fever that kills in a very short time $(20 \%)$ ", I don't know the meaning of COVID-19 (10\%).

\subsection{Signs \& symptoms of COVID-19}

Respondents answered questions to help researchers to gauge whether responds' perceptions about the signs and symptoms of COVID-19 posed a threat to public health. The study found out that only $70 \%$ of the participants reported knowing the true signs and symptoms of COVID-19. Some of the correct answers included, "cough and flue (70\%)", breathlessness (20\%), fever (30\%), and general body weakness $(10 \%)$. Some of the wrong answers included, "I don't know the signs and symptoms of COVID-19 because I have never seen such a patient", "I have never been told about the signs and symptoms of COVID-19". The common symptoms that were never mentioned by all the respondents were; headache, sore throat, nausea, and loss of taste \& smell.

\subsection{Prevention of community transmission of COVID-19}

All the respondents had some correct information about the recommended guidelines for preventing the community spread of COVID-19. The correct answers that were unanimously reported by the respondents include: wearing masks, avoiding crowded places, evasion of unnecessary travels, and good handwashing practices. $80 \%$ of the respondents did not indicate that it was necessary to use soap while washing hands. The percentage of respondents that mentioned each of the intervention strategies is shown in Fig. 4 below.

\subsection{Perceptions on the COVID-19 pandemic}

To gauge if the respondents' perception about the extent of spread of COVID-19 in Uganda is a threat to public health, they were asked questions that were evaluated on a scale ranging from; "very important", "minimally important", "Not important" and "I don't know". The findings are summarized in (Table 2). 
Table 2

Perception about the COVID-19 burden

\begin{tabular}{|c|c|c|c|c|c|}
\hline $\begin{array}{l}\text { To what extent do you think the } \\
\text { following contribute to the spread of } \\
\text { COVID-19? }\end{array}$ & $\begin{array}{l}\text { Not } \\
\text { important }\end{array}$ & $\begin{array}{l}\text { Minimally } \\
\text { important }\end{array}$ & $\begin{array}{l}\text { Moderately } \\
\text { importation }\end{array}$ & $\begin{array}{l}\text { Very } \\
\text { important }\end{array}$ & $\begin{array}{l}\text { Don't } \\
\text { know }\end{array}$ \\
\hline $\begin{array}{l}\text { High COVID-19 prevalence in the } \\
\text { community }\end{array}$ & $1,10 \%$ & $2,20 \%$ & $3,30 \%$ & $3,30 \%$ & $\begin{array}{l}1, \\
10 \%\end{array}$ \\
\hline A belief that COVID-19 truly exists & $0,0 \%$ & $0,0 \%$ & $1,10 \%$ & $9,90 \%$ & $0,0 \%$ \\
\hline COVID-19 is very contagious & $0,0 \%$ & $1,10 \%$ & $2,20 \%$ & $5,50 \%$ & $\begin{array}{l}1, \\
10 \%\end{array}$ \\
\hline Hygiene & $0,0 \%$ & $0,0 \%$ & $0,0 \%$ & $10,100 \%$ & $0,0 \%$ \\
\hline Access to information on COVID-19 & $0,0 \%$ & $1,10 \%$ & $3,30 \%$ & $7,70 \%$ & $0,0 \%$ \\
\hline $\begin{array}{l}\text { Willingness to adhere to health } \\
\text { guidelines }\end{array}$ & $1,10 \%$ & $1,10 \%$ & $2,20 \%$ & $6,60 \%$ & $0,0 \%$ \\
\hline Accessibility to sanitizers & $0,0 \%$ & $0,0 \%$ & $0,0 \%$ & $10,100 \%$ & $0,0 \%$ \\
\hline $\begin{array}{l}\text { People's inconsiderate desire to } \\
\text { exercise freedom of association \& } \\
\text { work }\end{array}$ & $1,10 \%$ & $1,10 \%$ & $3,30 \%$ & $4,40 \%$ & $\begin{array}{l}1, \\
10 \%\end{array}$ \\
\hline $\begin{array}{l}\text { Inappropriate COVID-19 control } \\
\text { measures }\end{array}$ & $0,0 \%$ & $1,10 \%$ & $3,30 \%$ & $5,50 \%$ & $0,0 \%$ \\
\hline $\begin{array}{l}\text { Unclear COVID- } 19 \text { case reporting \& } \\
\text { management procedure }\end{array}$ & $0,0 \%$ & $0,0 \%$ & $4,40 \%$ & $4,40 \%$ & $\begin{array}{l}2, \\
20 \%\end{array}$ \\
\hline Contact tracing & $0,0 \%$ & $1,10 \%$ & $1,10 \%$ & $8,80 \%$ & $0,0 \%$ \\
\hline
\end{tabular}

\subsection{Roles of local council leaders in the management and control of community transmission of COVID-9.}

Eighty percent of the local leaders were aware that their involvement in the control of COVID-19 was officially mandated by the government of the Republic of Uganda in a gazette. The remaining $20 \%$ reported that they were performing these tasks out of curiosity. The roles of local council leaders in the fight against COVID-19, mentioned by the respondents in this research were divided into three categories below.

\subsubsection{Response to alert cases}

The local council leaders were examined on how they would respond to potential COVID-19 cases notified to them in their villages of jurisdiction. The most frequent response was, "I alert the concerned health personnel to come and take control", $90 \%$. Others included; "I mobilize local council committee members to cordon off the home and then notify the government internal security officer (GISO) who directs the 
district health team to come and take charge", 80\%; "I give first aid followed by inviting government authorities to manage the situation", 10\%; and "I take no action", 10\%.

\subsubsection{Enforcing public health guidelines and government directives to curb COVID-19 spread}

Participants that confirmed to be actively engaged in the control of COVID-19 in their respective villages were asked to explain their role(s). The majority of the respondents reported to disseminate COVID-19 information by word of mouth via regular door-to-door meetings, and to remind these residents about the need for unrelenting conformity to COVID-19 prevention guidelines. Other responses included: monitoring and regulation of public ceremonies especially burials and weddings, and ensuring that visitors that come from distant places outside the village are reported and registered in the L.C I office by their hosts who are known, residents. Convening of village council meetings to brainstorm about better ways of implementing the COCID-19 guidelines was reported by $10 \%$ of the clients.

\subsubsection{Materials necessary for preventing COVID-19 spread}

The study revealed the inability of the residents to buy face shields/masks, and basic hygiene materials such as bar soap and recommended sanitizers. Some villages in Butalejja district were reported to have received minimal COVID-19 aid in form of soap from a Non-Government Organization called CHLORINE. All the respondents were hopeful to receive some material aid from higher authorities since the government of Uganda had already offered aid in form of food, milk, soap, sugar, and masks, to needy populations in some parts of urban Uganda.

\subsubsection{Opinions of local council leaders about the COVID-19 pandemic}

\section{In-depth interviews}

All the respondents were involved in in-depth interviews to seek their opinions about vital aspects of the COVID-19 pandemic. The respondents consented to be audio-recorded. A total of six main themes relating to the opinions of local leaders about the COVID-19 were identified using thematic analysis. The themes have been summarized in (Table 3 ) below. 
Table 3

Themes identified during the analysis of the opinions of local council leaders about the COVID-19 pandemic

\section{Themes Sub-themes}

(1) Inadequacy of community compliance to

COVID-19 preventive guidelines

$$
\begin{aligned}
& \text { Homesteads } \quad \text { - Hand-washing equipment in homesteads are } \\
& \text { increasingly becoming } \\
& \text { - scarce } \\
& \text { - Some families still host long-distance visitors of } \\
& \text { unknownCOVID-19 } \\
& \text { - status } \\
& \text { - Inter-home movements especially among children } \\
& \text { - Corporate personnel from distant places, such as } \\
& \text { researchers \& tourists, interact with residents at } \\
& \text { times without proper observance of COVID-19 } \\
& \text { guidelines } \\
& \text { - Burial ceremonies } \\
& \text { - Communal cultural events } \\
& \text { - Political gatherings } \\
& \text { - Sports events }
\end{aligned}
$$

(2) Hinderances to effective participation of local leaders in the fight against COVID-19
Communication challenges
- Deficiency of communication equipment like televisions, radios, etc.

- Those with radios at times lack funds to procure dry cells

- Poor quality of radio and television signals

- Poor quality of internet network

- National COVID-19 information is mostly communicated in English

hence the language barrier in rural populations 
Facilitation

- Inadequacy of finances and vehicles to support the intra-village movement of local leaders engaged in COVID-19 advocacy

- Lack of COVID-19 information resources such as posters

- Some leaders lack personal protective equipment

- Some areas are hard to reach due to mountainous terrain

- Long-distance to COVID-19 treatment and isolation centers

Awareness

- Some leaders are not knowledgeable enough about essential information on effective control of COVID19

- Illiteracy among most rural residents poses challenges in perceivingCOVID-19 information from leaders and other stake holders

Community perceptions

Insecurity

- Some citizens believe COVID-19 does not exist

- Cultural supremacists are opposed to the suspension of massive traditional gatherings \&rituals such as funeral rites \& circumcision events

- Religious supremacists believe the protection of lives is a sole duty of God

- Some residents believe that local council leaders are unsuitable to guide and monitor COVID19 matters

- Local leaders intimidated by residents who are unhappy about COVID-19restrictions

- Local leaders deserted by friends who feel disturbedbyCOVID-19

restrictions

(3) Factors promoting the effective contribution of local leaders in the fight against COVID-19
Communication competences
- Fluent in local languages understandable to rural communities

- Most village leaders are capable of grasping and communicating common COVID-19 preventive measures set by the health ministry 


\section{Mandate}

(4) Resources needed by communities to alleviate COVID-19 spread
Protective equipment

Hygiene requirements
- Uganda's ministry of health established a gazette in which village

leaders are mandated to engage in the fight against the community spread of COVID-19(14).

- The fact that Uganda's president publicly announced the necessary role of village leaders in fighting COVID-19spread motivated most of these leaders and aroused confidence in the residents they lead.

- Face masks are scarce in rural settings

- Gloves are expensive to low-income earners

- Soap relatively expensive to most rural residents

- Commercial sanitizers are scarce in rural settings

- Clean water is at times hard to find in some rural areas

Access to health services \&information

- Adequate COVID-19 isolation and treatment facilities
- Limited by the inadequacy of media equipment such as Radios

- A small number of village council leaders compared to sizes of populations they lead

- Village health officers seldomly reach out to rural communities

but remain limited by challenges of; being few compared to the

population, the inadequacy of resources and remoteness of some villages

(5) Impact of COVID-19 Economic on communities activities
- COVID-19 restrictions on public transport hinder the delivery of rural

agricultural yields to urban markets, reducing income generation

- Prices of rural agricultural products fell due to reduced availability of

potential buyers 
Education

Crimes

- Teenage pregnancies are on the rise among school children forced to stay home due to the suspension of schools after the COVID-19 outbreak

- Child labor is on the rise\& might ruin attitude towards education

- Teachers and farmers that supply agricultural produce to schools are experiencing a heavy scarcity of finances and difficult survival

- Reports of theft increased due to restrictions on people's businesses

- Reports of child abuse increased

- Reports of misunderstandings and fights among couples increased

Social wellbeing - Many people are psychologically disturbed by restrictions on free interaction and leisure

Health

- Prioritized fight against COVID-19 led to difficult access to treatment of other chronic diseases such as HIV/AIDS, in rural communities.

Political stature

- Individuals currently contesting for political positions face limited access to electorates, hindering chances of winning the fast-approaching elections

- Residents have inadequate opportunity to appraise the political candidates and make informed choices of new leaders in the next elections

- Locked down communities exert overwhelming demands for food aid and other necessities to the leaders who then become financially strained

(6) Recommendations for improving COVID-19 mitigation
Material support
- Aid desired for rural communities in form of face shields, soap, sanitizers, food and other resources necessary in COVID-19 prevention

- Need for financial support to rejuvenate the businesses hard-hit by the COVID-19 burden

Infrastructure - Improved clean water supply systems\& healthcare infrastructure in rural settings

COVID-19

screening
- Need for routine surveys to identify asymptomatic careers of COVID-19 in rural communities

- Politicians desire mandatory COVID-19 screening before holding political activities in communities 
Sensitization

- Village health teams (VHTs) ought to intensify sensitization of rural communities about COVID-19

- Local leaders owe to be trained better about COVID19 management, to support the communities, they lead more effectively

\subsection{Observational survey to examine the potential risk of community transmission of COVID-19 in rural districts in Eastern Uganda.}

We conducted an observational survey to identify factors that may exacerbate the spread of COVID-19 in the resource-poor communities of Eastern Uganda. The observed factors belonged to five categories namely; geographical factors, economic factors, social factors, community-based anti-COVID-19 advocacy, and the homestead environment. The observations made in each of the five categories above were checked against the guidelines for curbing the community spread of the COVID-19 pandemic, provided by the World Health Organization and the Ministry of health of the government of the Republic of Uganda $(14,17)$. Our observational survey revealed the following findings:

\subsubsection{Geographical factors}

The districts involved in this study were found to be potentially vulnerable to imported COVID-19 cases from Kenya by virtue of being near the porous Kenya-Uganda border. Sironko and Bulambuli districts share borders with Kenya to the east, while Butalejja is bordered to the East by Tororo district which links to the Uganda Kenya border. This makes these districts prone to imported COVID-19 cases from Kenya, a country that has been listed among the most vulnerable to, and most hit by COVID-19 in the East African region $(3,19)$. Steep mountain Elgon ranges observed in most parts of Bulambuli and Sironko districts (Fig. 5), may hinder health service delivery, hence escalating COVID-19 spread.

\subsubsection{Safe water resources}

Pertaining to the availability of safe water resources, the water that flows continuously from mountain Elgon ranges was found to be trapped in an open environment and used domestically by some residents in Sironko and Bulambuli districts. In Butalejja district, river Mpologoma was reported to be a main, yet distant source of water for domestic use among some residents. Pertaining accessibility to the rural areas where this study was conducted, the steep mountainous terrain observed in Bulambuli and Sironko districts may delay the management of the COVID-19 cases, hence increasing the transmission risk.

\subsubsection{Social factors}


The interactions among people who inhabit public places such as markets, shops, and sports facilities were observed to check for conformity to the guidelines established by WHO to alleviate the spread of COVID-19 in public places(17). The study found out that, there was a violation of COVID-19 preventative guidelines. Though face masks were seen displayed in most shops, they were mostly not worn by individuals who closely interacted in public places. Though suspended by the government of Uganda to curb the spread of COVID-19, several community gatherings such as sports events were rarely observed taking place in some villages. Figure. 6 below shows a gathering of residents in Butalejja district illegitimately dancing "Kadodi", a prominent traditional dance, to celebrate victory after a prominent resident won a local leadership position.

The temporary closure of schools to curb the COVID-19 spread was observed to be associated with visible consequences in the areas where this study was conducted. For example, on several occasions, children of school-going age were observed mixing up in different public events especially in sports fields, and burial ceremonies; contrary to the COVID-19 control guidelines.

\subsubsection{Economic factors}

We observed that most farmers accumulated enormous agricultural produce but were unable to receive sufficient buyers who had been trading and delivering such harvests to distant urban centers during the pre-COVID-19 era. This elicited visible indicators of monetary poverty among most of the residents since agriculture is their cardinal source of income and livelihood. In the non-agricultural business ventures such as general merchandise shops; restaurants and saloons; social distancing, sanitizers, handwashing gadgets, and the wearing of masks were uncommon.

\subsubsection{Homestead environment}

We made observations to assess conformity to COVID-19 preventive guidelines in homesteads $(17,18)$. Handwashing gadgets were scantly seen in a few homes and these had been developed from locally available materials such as banana fibers, shrubs, and plastic cans (Fig. 7).

The housing structures observed in the study area were generally not sizeable enough to effectively accommodate the recommended home-based COVID-19 management given the large family sizes in most homes as shown in Fig. $8(11,15)$.

Regarding the dietary recommendations for COVID-19 management, we watched out for the presence within the communities, of the fruit crops that have been highlighted as potentially beneficial in boosting the body's immunity to fight respiratory viral infections such as COVID-19. The most important are fruits that are rich in zinc, selenium, and vitamins $C \& D$, especially citrus fruits such as lemons and oranges(20).Our observations revealed a considerable scarcity of these vital dietary supplements in most of the homesteads and gardens visited. Instead, the frequently cultivated fruits observed in these communities were Jackfruits, Mangoes and Bananas.

\subsubsection{Community based anti-COVID-19 advocacy}


We watched out for visible items potentially established in the community by community-based organizations, authorities, or interest groups, that would increase awareness and improve the community's attitudes towards the fight against COVID-19. Such items would include posters, banners, billboards, stickers that are designed with COVID-19 related information. Our observations revealed no evidence of such vital informative items in the study area.

\section{Discussion}

\subsection{Socio-Demographic Characteristics}

Ten local council leaders in charge of six villages from three districts, viz; Sironko, Bulambuli, and Butalejja, in Eastern Uganda participated in this study. Most of the participants were males since top the leadership of village councils in Uganda is exclusive to men. Most participants (50\%) fell in the age category of $\geq 60$. Though $60 \%$ of the participants attended primary education, none of the respondents completed an ordinary level of education to attain the Uganda Certificate of Education (UCE).

\subsection{Knowledge and perceptions about the COVID-19 pandemic}

Though all the respondents reported having received some information about the existence of the COVID19 pandemic, there was generally low knowledge and awareness about some crucial aspects of the pandemic. The majority (70\%) of the respondents did not know the meaning of COVID-19, while $100 \%$ were unaware of some common symptoms such as; headache, sore throat, nausea, vomiting, malaise, muscle pain, diarrhea, loss of taste \& smell among others(18). Low knowledge levels about COVID-19 might be partly attributed to the high illiteracy levels among the respondents, since none of them attained the ordinary Uganda Certificate of Education (UCE). Elsewhere, low education levels have been associated with limited ability to comprehend health information, hence predisposing communities to a higher risk of disease transmission (21). Similar to prior research (22-24), our study revealed that radio $(9 ; 90 \%)$ was the main source of health information used by the respondents. The scarcity of hydroelectricity power might explain why some information sources such as televisions and the internet were uncommon. Our findings were however in discrepancy with some recent studies conducted in Nigeria and in the United States of America (USA) where other sources of health information besides radio were utilized more(25, 26). In the USA, majority of respondents reported reliance on health professionals as sources of health information, and that age, income and education influenced people's choice of health information sources (26).

Some clients (10\%) falsely believed that the COVID-19 pandemic was a fallacy in Uganda. This misconception may be attributed to the scarcity of genuine COVID-19 information which has created room for the spread of wrong information about the pandemic, especially in rural settings. Most of the participants believed that; hygiene, accessibility to health information, belief that COVID-19 truly exists, contact tracing, and access to sanitizers $(100 \%, 80 \%, 90 \%, 100 \%$, and $70 \%)$ were very important in 
influencing the control of COVID-19; while 10\% did not know whether high prevalence rates, willingness to adhere to health guidelines and people's desire to exercise freedom of association \& work, could have significant impacts on control of COVID-19. Failure to appreciate the importance of these crucial epidemiological factors poses a threat to the effective prevention of the pandemic.

\subsection{Roles of village leaders in the management and control of community transmission of COVID-9.}

Participants who confirmed to be formally involved in the fight against COVID-19 in the villages they administer were eighty percent (8; 80\%). Similarly, in Thailand, the enormous role of Village Health Volunteers (VHVs), particularly local people or village leaders, in community-based surveillance (CBS) and reporting of highly contagious viral infections has been reported (27). In Thailand, the VHVs were subjected to basic training on how to recognize disease occurrence prior to their engagement in the CBS.

Most participants reported that they respond to alert cases by inviting the concerned government officials and health professionals to manage the cases. This action is appropriate since it rhythms with the Ugandan Ministry of Health's guidelines (14). Some respondents (10\%) reported that they offer first aid to COVID-19suspects, while others reported "taking no action". The former may accelerate the spread of the pandemic because local council leaders do not have the expertise and mandate to administer any treatment to COVID-19 suspects, while the latter incurs a public health threat since village council leaders are potentially the most immediate government officials available in remote rural settings, and owe to respond appropriately to COVID-19 notification. This is authenticated by the COVID-19 gazette of the government of Uganda (14).

The commonest approaches employed by most respondents to engage in the fight against COVID-19 were; dissemination of COVID-19 information by word of mouth through door-to-door meetings, regulation of public ceremonies such as burials and weddings, and monitoring of visitors that come from distant places. Though these approaches are generally tedious in the event that the personnel lack adequate financing, they have reportedly been employed in other countries $(25,28)$. For example, a study by Anna Biley et al., 2000 in the United Kingdom reported word of mouth as a commonly used avenue of conveying health information, followed by leaflets, television, and newspapers (28).

Most respondents reported that residents in the villages where this study was conducted had not yet received any aid in form of masks, soap, sanitizers or food, to enhance effective prevention of COVI-19 as reported in some urban parts of Uganda (29), except for some villages in Butalejja district where the residents had received minimal aid in form of soap from a non-government organization called CHLORINE. Generally, the deficiency of materials that are essential in preventing COVID-19 among rural communities was evident.

\subsection{Opinions of local leaders about the COVID-19 pandemic}

The respondents believed that in the areas where this study was conducted, the degree of community compliance to COVID-19 preventive guidelines was declining drastically at both the household level and 
in public places. This could be explained by low awareness, inadequate anti-COVID-19 campaigns, and falsified belief of some residents in these rural villages about the non-existence of COVID-19 pandemic in Uganda. The implication is that rural communities in Eastern Uganda are potential candidates for a drastic upsurge of COVID-19 and hence severer damage. Though the respondents were certain about factors that favored their effective participation in the fight against this pandemic, they iterated that their contribution to the fight against COVID-19 was hampered mostly by limited access to COVID-19 information, the inadequacy of communication resources accessible to the rural communities such as radios, high levels of illiteracy among the communities, long-distance to COVID-19 treatment and isolation centers, plus the fact that some of their subjects believed that the village council leaders were not suitable to engage in matters of critical public health importance such as COVID-19.

The respondents opined that the COVID-19 pandemic had incurred negative impacts on both rural and urban communities, with some of the notable cases being; loss of wages and income, loss of human capital, straining of the health sector as well as disruption of social wellbeing and liberty to associate. These opinions are in tandem with several reports which have assessed or projected the adverse socioeconomic impacts of COVID-19 on several countries including Uganda, Kenya, United Arab Emirates, and Mexico among others $(30,31)$.

The respondents also mentioned interventions that may improve preparedness and response to COVID-19 in rural settings, and hence minimize the damage incurred by the pandemic. These included; provision of aid in form of materials necessary for COVID-19 control such as soap and masks, scaling up the water supply and health systems, routine surveys to identify potential asymptomatic COVID-19 cases, and improving health awareness creation.

\subsection{Potential risk of community transmission of COVID-19 in rural districts in Eastern Uganda.}

The key geographical factors that potentially posed a risk of COVID-19 upsurge to the areas included in this study were: proximity to the porous Kenya-Uganda border(32), hence increased susceptibility to imported COVID-19 cases; tapping water from open sources such as river Mpologoma by a section of the population; and the presence of a mountainous terrain which complicates accessibility hence straining case management. Regarding the porous borders, the potential contribution of people entering Uganda from Kenya, possibly via informal entry points, to the rise of COVID-19 cases in Uganda has been acknowledged previously(8). Also, challenges related to mountainous terrain have been implicated in impeding health service delivery in other countries such as Britain(33). Further, the fact that some of the community members in Butalejja district fetch water from river Mpologoma creates public health concerns with regard to COVID-19 spread. This river receives its water supply from various streams especially from Mountain Elgon; and it flows through several districts in Eastern Uganda, including COVID-19 hotspots such as Mbale district and Tororo district $(34,35)$. Pollution of river Mpologoma, including sewerage discharge by humans in these hotspots, has been reported (36). This poses a threat 
to rural communities that use this water downstream since the COVID-19 pathogen (SARS-Cov.2) has been proved to survive in sewerage and in untreated waters in some places $(37,38)$.

With regard to social factors, breaching of the WHO public health guidelines and the Ugandan government directives set to fight COVID-19 was observed in public places such as markets, streets, sports grounds and all other community gatherings. Commonest indicators included scarcity of maskwearing \& hand-washing resources, and lack of social distancing. This may partly be attributed to the inadequacy of COVID-19 awareness campaigns that would rather be implemented in avenues such as songs, posters, banners, and billboards in the rural communities. In Nigeria, low health awareness was associated with an increased risk of disease spread and decline of the overall public health quality (39).

Economically, we observed the undue presence of commercial perishable agricultural produce such as bananas and tomatoes in rural communities. This could be explained by financial constraints and transportation challenges incurred by COVID-19 restrictions on the traders who deal in conveyance of agricultural merchandise from rural villages to urban markets. The consequence is a potential risk of financial losses incurred to the farmers, and hence impairing their ability to meet the monetary demands of COVID-19 prevention and treatment.

At the homestead level, the availability of locally innovated handwashing gadgets (Fig. 7), was the major and sole indicator of community responsiveness to the COVID-19 pandemic. Though these gadgets were scarcely present, and with no soap availed in some cases, they rather exhibited a positive attitude towards alleviation of this pandemic by the rural communities amidst resource constraints. We also observed that in most cases, the sizes of houses were not commensurate to the large families, in light of the high populations situated in Uganda's rural settings as compared to urban places (11). The consequence is a potential risk of inhouse accelerated COVID-19 in-house spread in rural communities. Also, we observed the scarcity in homesteads, of food staffs which have been recommended in boosting the body's ability to fight respiratory viruses such as SARS-Cov.2 (20). This may pose treatment challenges in the case of COVID-19upsurge in these remote rural villages.

\subsection{Conclusion and recommendations}

Rural communities in Eastern Uganda are vulnerable to the explosive spread of COVID-19, due to challenges related to; low awareness of COVID-19, reluctance in complying with preventive guidelines, finance, technology, terrain, porous borders, scarcity of protective wear and hygiene resources, and Illiteracy. Awareness creation, material aid, execution of preventive rules, and more research on COVID-19 are warranted.

\section{List Of Abbreviations}

COVID-19; coronavirus disease 2019, UNDP; United Nations Development Program, UBOS; Uganda Bureau of Statistics, UNICEF; United Nations Children's Fund. 


\section{Declarations}

\section{Ethical approval and consent}

The study sought approval from the institutional review board of the Islamic University in Uganda. Village council authorities also permitted this study. The research was conducted in conformity to the national guidelines for the conduct of research in the COVID-19 era established by the Uganda National Council for Science and Technology (UNCST) (40). Participants provided voluntary informed consent prior to participation in the study. Respondents' identifiers were recorded in form of assigned codes instead of names to ensures anonymity. All information from the participants was kept confidential \& stored under lock and key and pass word protected electronic files were stored during data analysis.

\section{Consent for publication}

Not applicable

\section{Availability of data and materials}

Data sets generated and analyzed during this study are available from the corresponding author on reasonable request.

\section{Competing interests}

There were no competing interests in this study.

\section{Funding}

This research was funded under the research and innovation grant awarded to the Islamic University in Uganda (IUIU) by the Islamic Development Bank (IsDB).

\section{Authors' contributions}

"Abdul Walusansa (AW), Hawa Nabuuma (HN), and Jacob S. Iramiot (ISJ) conceived the research idea, participated in data collection \& analysis plan, and writing of the primary draft of the manuscript.

"Ali Kudamba (AK), Aidah Namuli (AN), Joseph Mpagi and Hussein M. Kafeero (HMK) participated in data collection, advised on the data analysis plan and were major contributors in writing the manuscript.

"Shaban A. Okurut (SAO), and Jamil. E. Ssenku (JES)were senior advisors and supervisors in the study, were major contributors in writing the manuscript and performed final editing of the manuscript.

All authors read and approved the final manuscript."

\section{Acknowledgements}

Not applicable 


\section{References}

1. Li Y, Liu X, Guo L, Li J, Zhong D, Zhang Y, et al. Traditional Chinese herbal medicine for treating novel coronavirus (COVID-19) pneumonia: protocol for a systematic review and meta-analysis. Syst Rev. 2020;9:1-6.

2. World Health Organization (WHO). WHO characterizes COVID-19 as a pandemic [Internet]. 2019. Available from: https://www.paho.org/hq/index.php? option=com_content\&view=article\&id=15756:who-characterizes-covid-19-as-apandemic\&ltemid=1926\&lang=en

3. World Health Organization (WHO). WHO Coronavirus Disease (COVID-19) Dashboard [Internet]. 2020 [cited 2020 Oct 29]. Available from: https://covid19.who.int/

4. United Nations Development Program (UNDP). Response to the COVID-19 pandemic in urban slums and rural populations in Latin America [Internet]. 2020. Available from:

https://www.latinamerica.undp.org/content/rblac/en/home/blog/2020/respuesta-a-la-pandemia-decovid-19-en-poblaciones-urbano-margin.html

5. World Health Organization (WHO). WHO COVID-19 Preparedness and Response Progress Report - 1 February to 30 June 2020 [Internet]. 2020. Available from:

https://www.who.int/publications/m/item/who-covid-19-preparedness-and-response-progress-report-1-february-to-30-june-2020

6. Kisakye F, Nakazibwe C. Uganda: Covid-19 - How Uganda Good Fight Went Wrong [Internet]. The Observer (Kampala). 2020 [cited 2010 Sep 25]. p. 1-2. Available from: https://allafrica.com/stories/202009020510.html

7. World Health Organization (WHO). COVID-19 Global live updates [Internet]. 2020. Available from: https://covid19.who.int/region/afro/country/ug

8. Natukunda. Kenyan national dies in Mbale after presenting Covid-19 related symptoms [Internet]. Daily monitor. 2020. Available from: https://www.monitor.co.ug/uganda/news/national/kenyannational-dies-in-mbale-after-presenting-covid-19-related-symptoms-1908506

9. Duerksen M. Innovations Needed to Prevent COVID-19 from Catching Fire in African Cities [Internet]. 20202. Available from: https://africacenter.org/spotlight/innovations-needed-prevent-covid-19catching-fire-africa-cities/

10. Daily Monitor. The loopholes in Covid-19 fight. 2020;1-2. Available from: https://www.monitor.co.ug/uganda/news/national/the-loopholes-in-covid-19-fight-1881302

11. United Nations D of E and S, Dynamics P. World Population Review [Internet]. 2019. Available from: https://worldpopulationreview.com/countries/uganda-population

12. Otim Richard. Uganda: Eastern, Northern Regions Grapple With High Illiteracy [Internet]. 2020. Available from: https://allafrica.com/stories/200611200819.html

13. Matee MI, Manyando C, Ndumbe PM, Corrah T, Jaoko WG, Kitua AY, et al. European and Developing Countries Clinical Trials Partnership (EDCTP): the path towards a true partnership. BMC Public 
Health. 2009;9(1):1-6.

14. Ministry of Health Uganda (MOH). The Uganda Gazette No. 19, Volume CXII: Public Health (Control of COVID-19) Rules, 2020 [Internet]. 2020. Available from: https://ulii.org/ug/legislation/statutoryinstrument/2020/52

15. Uganda Bureau of Statistics (UBOS). The national population and housing census 2014-main report. Kampala Uganda Bur Stat [Internet]. 2016; Available from: https://www.ubos.org/

16. U.S. Agency for International Development (USAID)/African and Latin American Resilience to Climate Change (ARCC). Chapter 3: Analysis of Vulnerability in Uganda [Internet]. 2019. Available from: https://www.ids.ac.uk/download.php?file=files/UgandaCh3.pdf · PDF file

17. World Health Organization (WHO). Coronavirus disease (COVID-19) advice for the public [Internet]. 2020. Available from: https://www.who.int/emergencies/diseases/novel-coronavirus-2019/advicefor-public

18. National Institute of Health (NIH). COVID-19 Treatment Guidelines [Internet]. 2020. Available from: file:///E:/COVID-19/WHO DOCS/covid19treatmentguidelines NIH.pdf

19. Muchira N. Kenya among states 'most vulnerable' to Covid-19 [Internet]. 2020. Available from: https://www.theeastafrican.co.ke/tea/science-health/kenya-among-states-most-vulnerable-to-covid19-1436896

20. De Faria Coelho-Ravagnani C, Corgosinho FC, Sanches FLFZ, Prado CMM, Laviano A, Mota JF. Dietary recommendations during the COVID-19 pandemic. Nutr Rev. 2020;

21. Zajacova A, Lawrence EM. The relationship between education and health: reducing disparities through a contextual approach. Annu Rev Public Health. 2018;39:273-89.

22. Smith ML, Menn M, McKyer ELJ. Effectiveness of the radio as a health information source. J radio audio media. 2011;18(2):196-211.

23. Burger J, Gochfeld M, Jeitner C, Pittfield T, Donio M. Trusted information sources used during and after Superstorm Sandy: TV and radio were used more often than social media. J Toxicol Environ Heal Part A. 2013;76(20):1138-50.

24. Duncan GI. The validity of health information gained through radio advertising... Temple university; 1944.

25. Gidado S, Oladimeji AM, Roberts AA, Nguku P, Nwangwu IG, Waziri NE, et al. Public knowledge, perception and source of information on Ebola virus disease-Lagos, Nigeria; September, 2014. PLoS Curr. 2015;7.

26. Cotten SR, Gupta SS. Characteristics of online and offline health information seekers and factors that discriminate between them. Soc Sci Med. 2004;59(9):1795-806.

27. Organization WH. Role of village health volunteers in avian influenza surveillance in Thailand. WHO Regional Office for South-East Asia; 2007.

28. Biley A, Robbe I, Laugharne C. Sources of health information for people with cancer. Br J Nurs. $2001 ; 10(2): 102-6$. 
29. Dinah M. Ugandan government distributes face masks in Kampala [Internet]. 2020. Available from: https://africa.cgtn.com/2020/08/09/ugandan-government-distributes-face-masks-in-kampala/

30. Kansiime MK, Tambo JA, Mugambi I, Bundi M, Kara A, Owuor C. COVID-19 implications on household income and food security in Kenya and Uganda: Findings from a rapid assessment. World Dev. 2020;137:105199.

31. United Nations Development Program (UNDP). No Title [Internet]. 2020. Available from: https://www.undp.org/content/undp/en/home/coronavirus/socio-economic-impact-of-covid-19.html

32. United Nations Children's Fund (UNICEF). Uganda-Kenya cross-border partnership rescues girls from female genital mutilation during COVID-19 [Internet]. 2020. Available from:

https://www.unicef.org/uganda/stories/uganda-kenya-cross-border-partnership-rescues-girls-femalegenital-mutilation-during-covid

33. Rajé F. Rural transport interventions to improve maternal health outcomes. 2018;

34. Kizito F, Ngirane-Katashaya G. An integrated, basin-wide planning approach for the River Malaba catchment. 2006;

35. Cecilia O, Faustine O. Tororo becoming a hotspot for COVID-19 community infections [Internet]. 2020. Available from: https://www.newvision.co.ug/news/1521810/tororo-hotspot-covid-19-communityinfections

36. Gerald M. Contamination of R. Nabuyonga, a catchment if R. Mpologoma [Internet]. 2019. Available from: https://nilepost.co.ug/2019/04/14/mbale-residents-to-sue-nwsc-over-contamination-of-rivernabuyonga/

37. Medema G, Heijnen L, Elsinga G, Italiaander R, Brouwer A. Presence of SARS-Coronavirus-2 in sewage. MedRxiv. 2020;

38. World Health Organization (WHO). Status of environmental surveillance for SARS-CoV-2 virus: scientific brief, 5 August 2020. World Health Organization; 2020.

39. Sofola 00. Implications of low oral health awareness in Nigeria. Niger Med J. 2010;51(3):131.

40. Uganda National Council for Science and Technology (UNCST). National guidelines for conduct of research during coronavirus disease 2019 (COVID-19) pandemic [Internet]. Kampala; 2020. Available from: www.uncst.go.ug

\section{Figures}




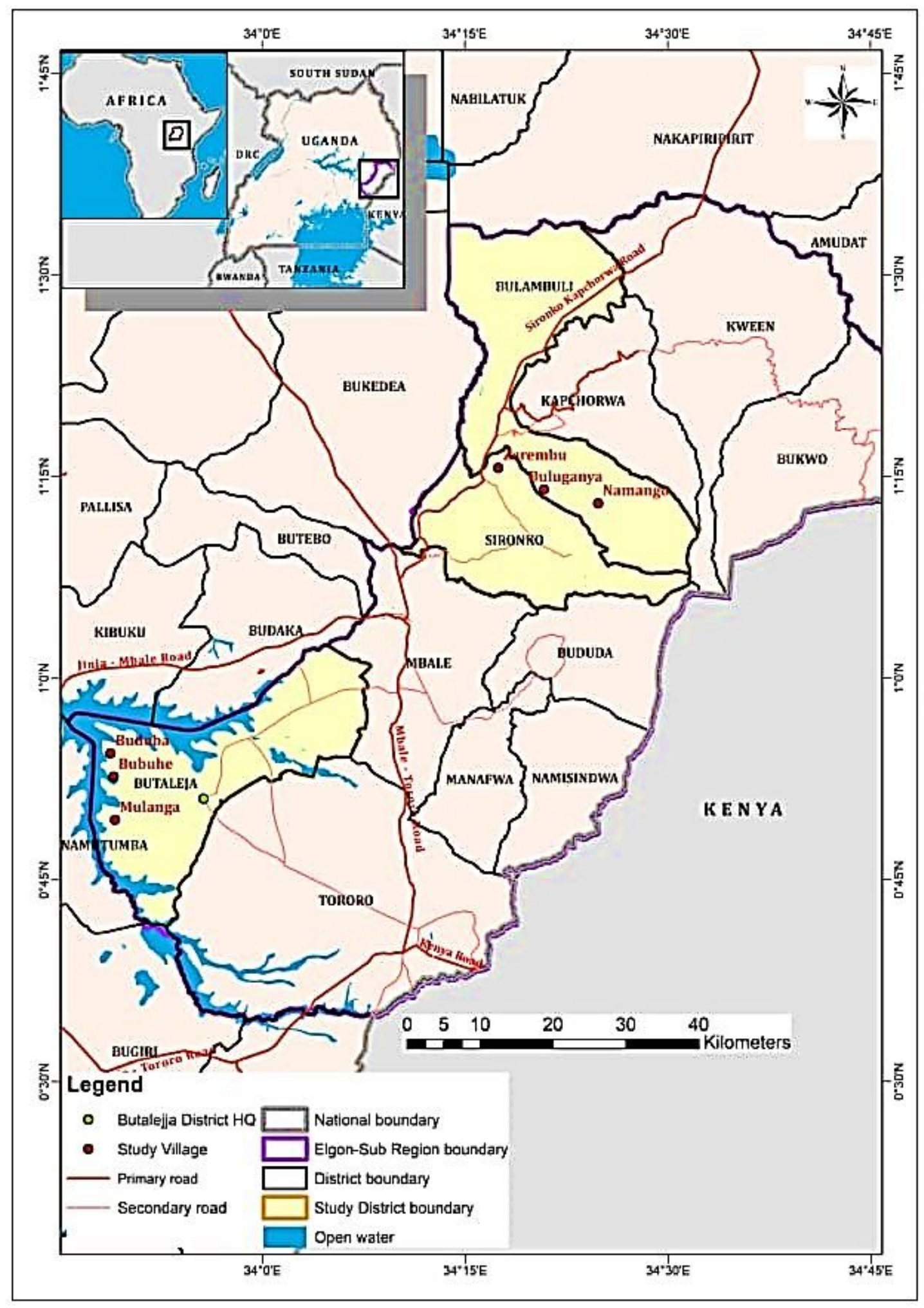

Figure 1

Map of Uganda showing the location of the study sites Note: The designations employed and the presentation of the material on this map do not imply the expression of any opinion whatsoever on the part of Research Square concerning the legal status of any country, territory, city or area or of its authorities, or concerning the delimitation of its frontiers or boundaries. This map has been provided by the authors. 


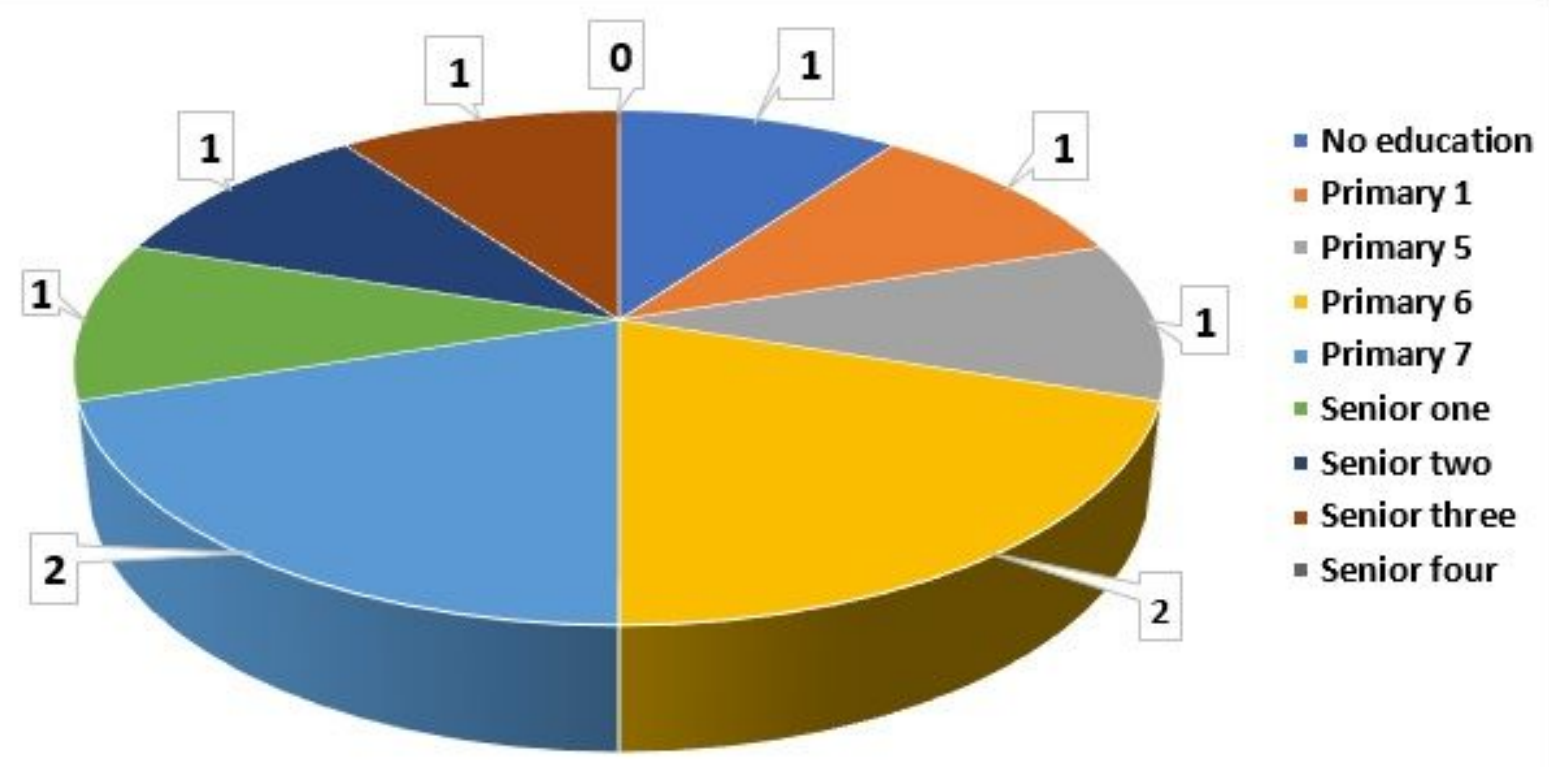

Figure 2

Education levels of respondents

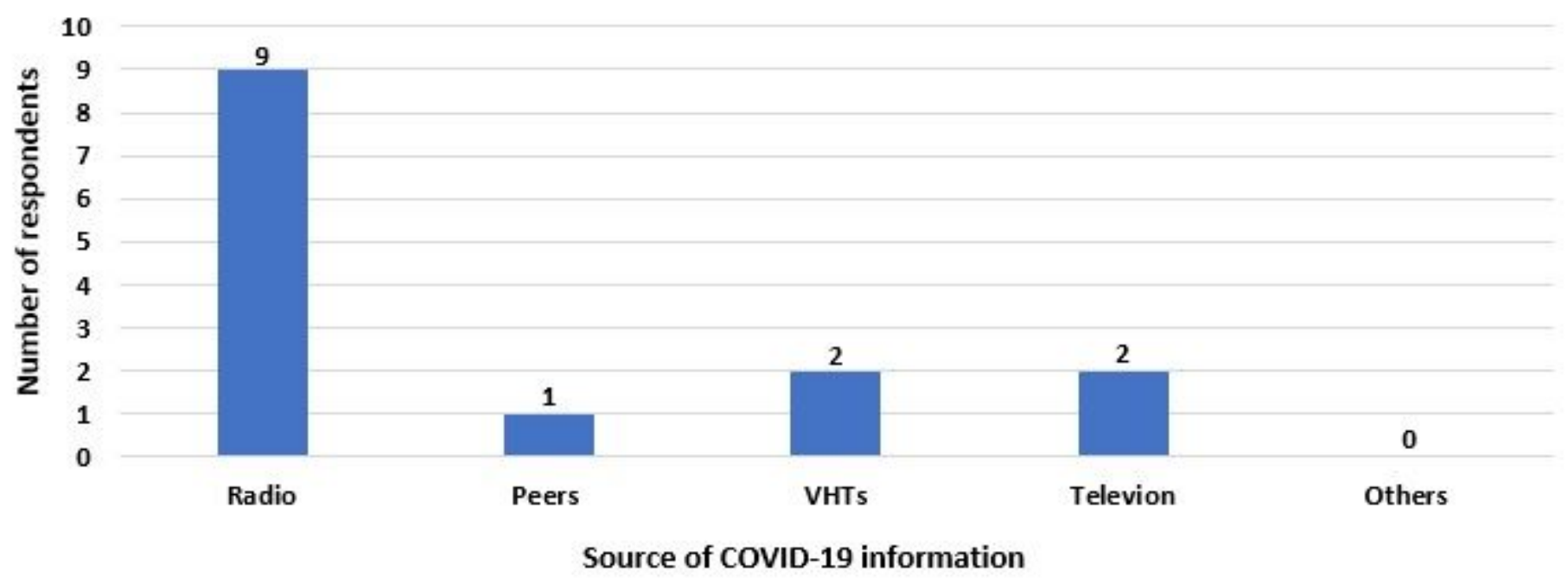

Figure 3

Source of information about COVID-19 among village leaders in rural communities in Eastern Uganda Key: Others $=$ Telephones, Social media, Posters and billboards; VHTs = Village Health Teams 


\section{What can one do to stop community spread of COVI-19?}

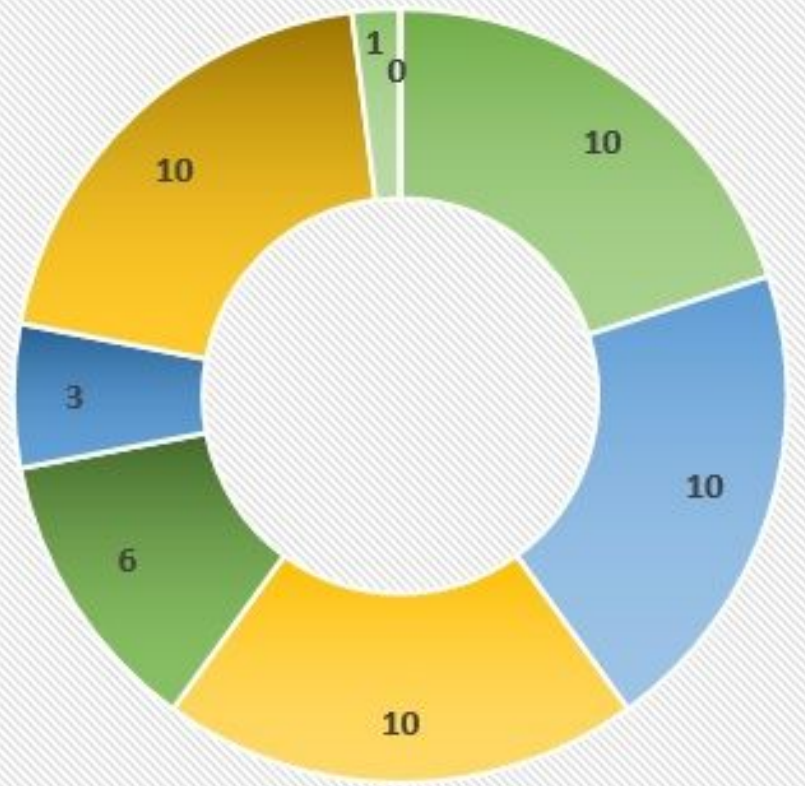

wearing of masks

- Avoiding crowded places

= Social distancing

n Evading unnecessary travels

- Avoid touching inanimate surfaces in public places

m Good hand-washing practices

= Conforming to governemnt directives such as lockdowns.

- cover your mouth and nose with tissue when you cough or sneeze/ do it inside your elbow \& do not spit.

neport to health personnel if you experience symptoms

\section{Figure 4}

Number of clients that correctly mentioned the strategies for alleviating community spread of COVID-19

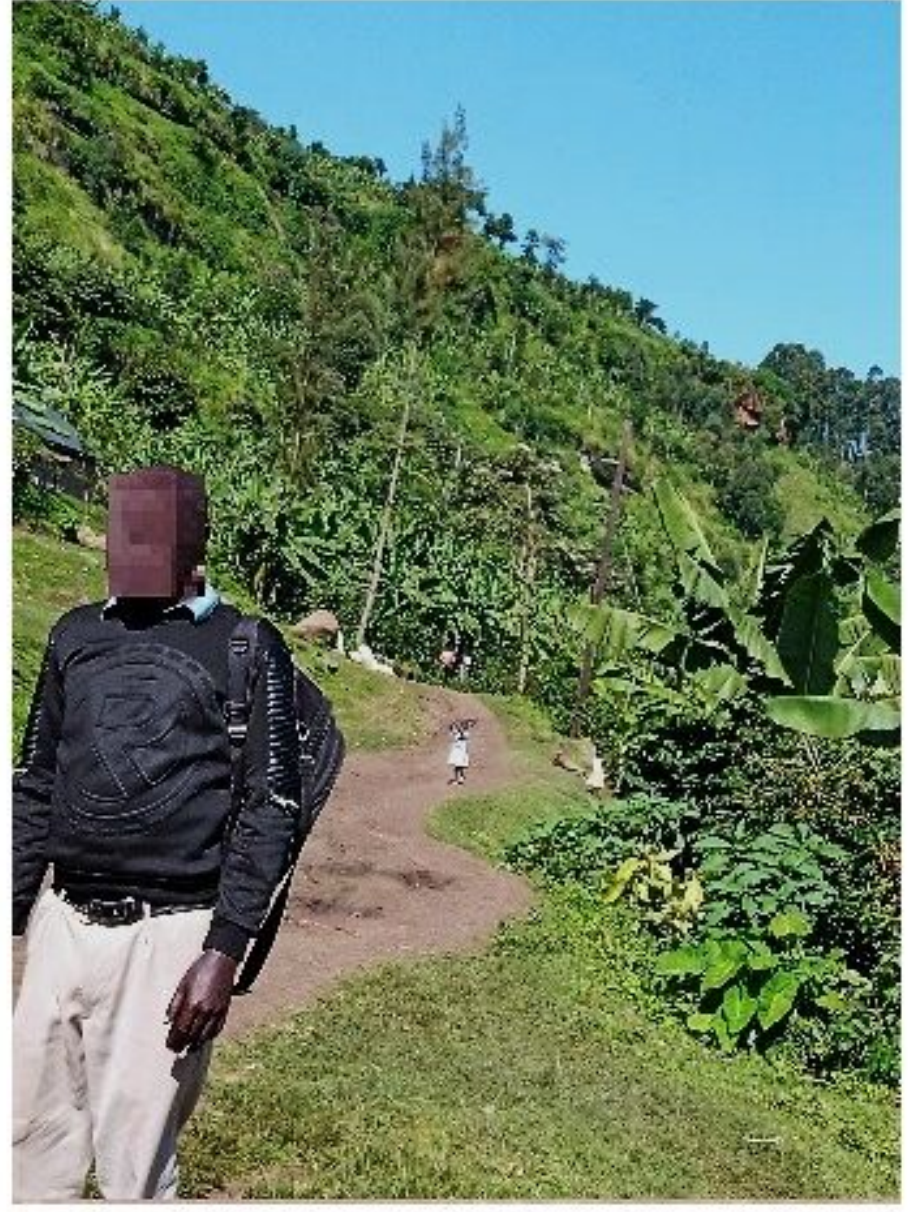




\section{Figure 5}

Mountainous terrain in Bulambuli District

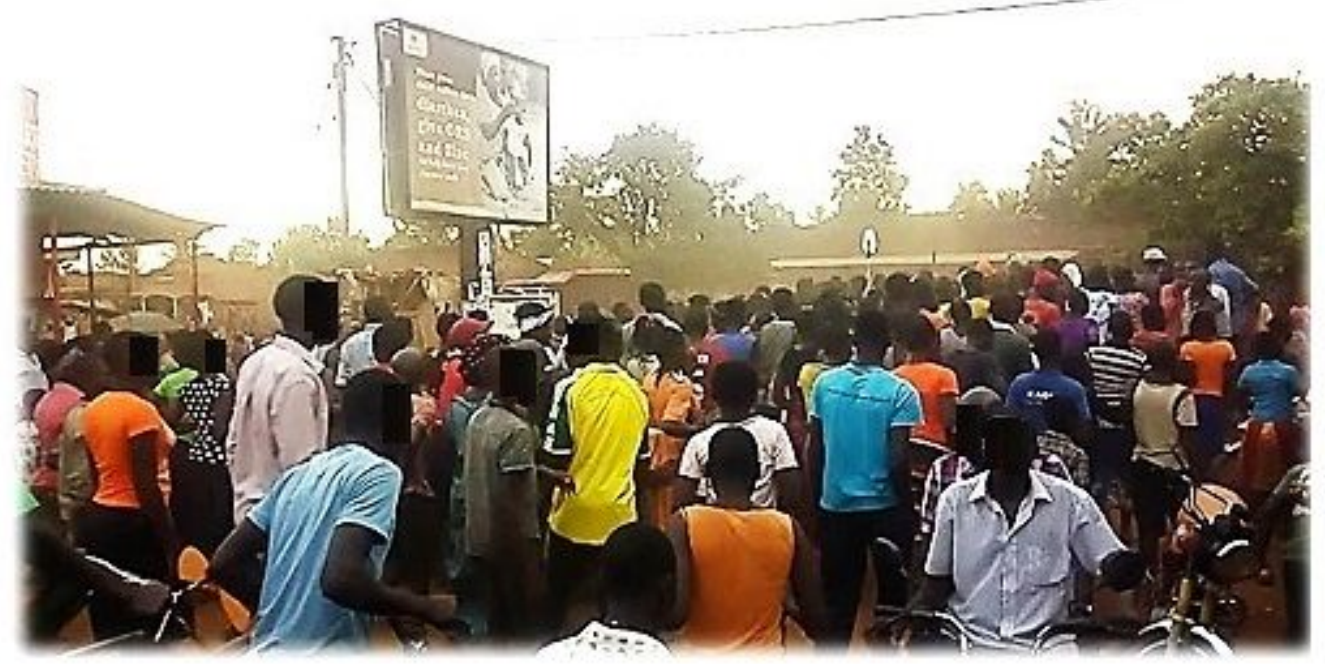

\section{Figure 6}

Residents in Butalejja district dancing "Kadodi" (traditional dance in Eastern Uganda), to celebrate the victory of a prominent resident for winning a village leadership position. This activity did not only violate the Ugandan government's ban on public gatherings but also the public health requirements of maskwearing and social distancing in public places.

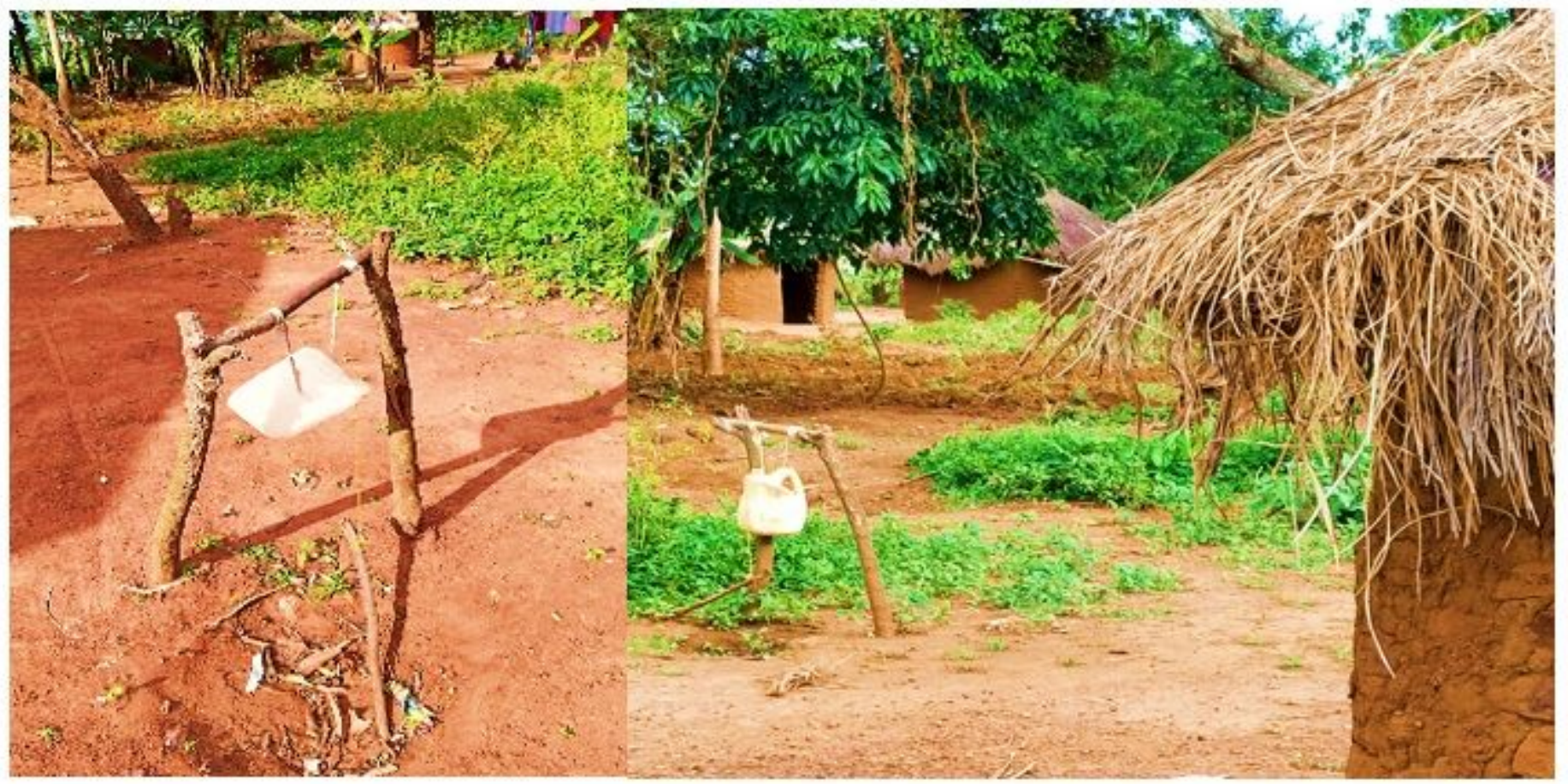

Figure 7 
A local handwashing apparatus innovated by a resident to counteract the community spread of COVID-19 in rural communities in Eastern Uganda. There was no soap or detergent observed in this hand washing set up

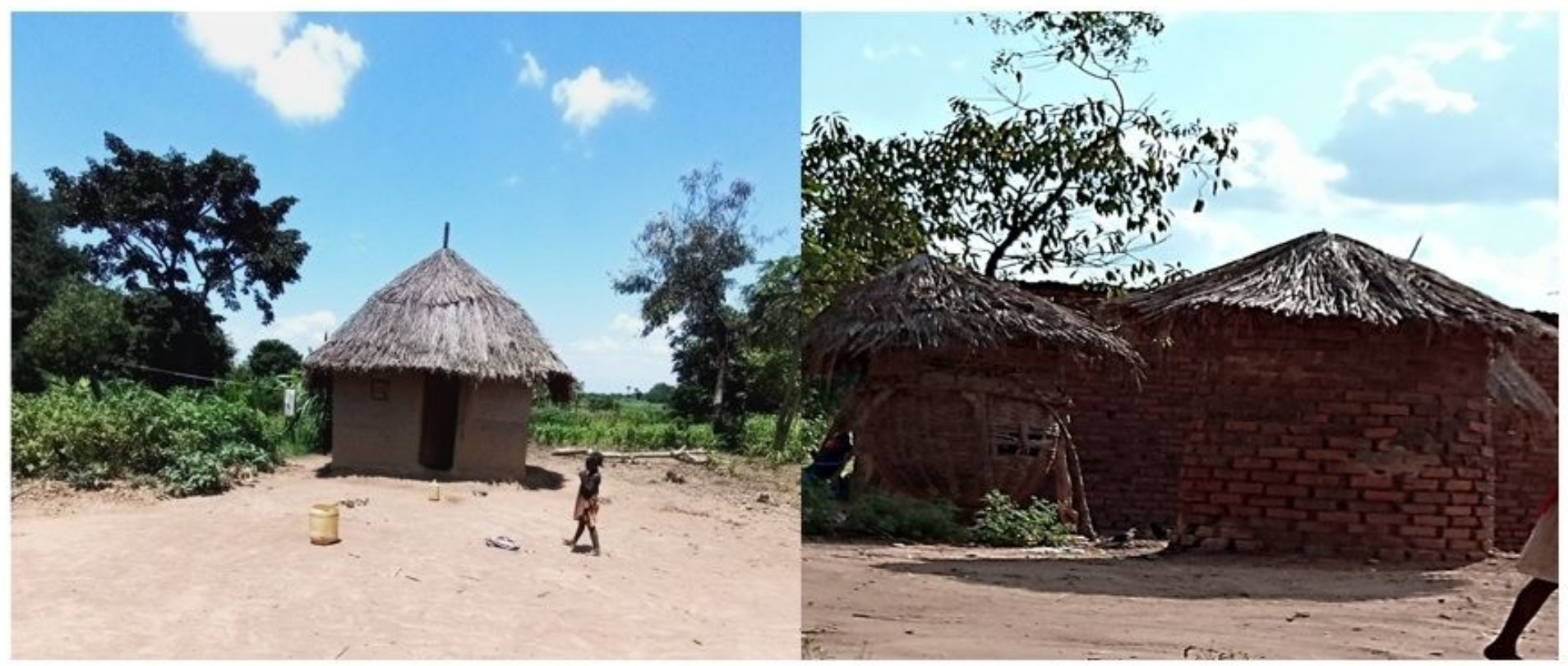

\section{Figure 8}

Some of the housing structures in rural communities in Eastern Uganda. 